\title{
PERFORMA PERTUMBUHAN BENIH IKAN BAWAL AIR TAWAR (Colossoma macropomum) YANG DIBERI PAKAN DENGAN TAMBAHAN KALIUM DIFORMAT
}

\author{
Ayi Yustiati, Kevin Aditya, Ibnu Bangkit Bioshina Suryadi dan Iskandar \\ Program Studi Perikanan, Universitas Padjadjaran \\ Jl. Raya Bandung-Sumedang KM. 21 Jatinangor, Sumedang, Indonesia \\ E-mail: kevinaditya1998@yahoo.com
}

\begin{abstract}
ABSTRAK
Ikan bawal air tawar (Colossoma macropomum) dimasukkan ke Indonesia dari Brazil pada tahun 1986, oleh sebuah perusahaan swasta, yang bergerak di bidang usaha budidaya ikan konsumsi, di Tangerang, Banten. Hasil penyebarannya mendapat respon dari para pembudidaya ikan di industri perikanan tanah air dan jumlah konsumsi ikan bawal air tawar semakin hari semakin meningkat. Pakan memiliki peranan penting dalam peningkatan produksi kegiatan budidaya. Pakan yang diberikan harus berkualitas tinggi, bergizi dan memenuhi syarat untuk dikonsumsi yang dibudidayakan. Riset ini bertujuan untuk menentukan dosis kalium diformat (KDF) yang paling efektif dalam pakan untuk meningkatkan laju pertumbuhan dan kelangsungan hidup ikan bawal air tawar (Colossoma macropomum). Riset ini menggunakan metode Rancangan Acak Lengkap (RAL) dengan 4 perlakuan dan 4 ulangan. Penelitian dilakukan selama 35 hari dengan sampling dilakukan setiap 7 hari sekali. Perlakuan yang digunakan adalah penambahan kalium diformat pada pakan komersil dengan dosis $0 \%, 0,1 \%, 0,3 \%$ dan 0,5\% per 100 gram pakan. Parameter yang diamati pada riset ini adalah kelangsungan hidup, laju pertumbuhan harian, efisiensi pemberian pakan dan kualitas air. Hasil menunjukkan bahwa pemberian dosis KDF $0,3 \%$ merupakan yang paling efektif untuk meningkatkan kelangsungan hidup, laju pertumbuhan harian dan efisiensi pemberian pakan dengan masing-masing nilai $100 \% ; 3,41 \%$; dan $90,78 \%$.
\end{abstract}

Kata kunci: Colossoma macropomum; Asam Organik; Pakan Tambahan; Pertumbuhan; Kelangsungan Hidup.

\section{GROWTH PERFORMANCE OF FRESHWATER POMFRET FINGERLINGS (Colossoma macropomum) WHICH USED POTASSIUM DIFORMATE (KDF) AS FEED ADDITIVES}

\begin{abstract}
Pomfret Fingerlings (Colossoma macropomum) was introduced to Indonesia from Brazil in 1986, by a private company, engaged in the business of consuming fish farming, in Tangerang, Banten. The results of its distribution received a response from the fish farmers in the land fishing industry and the amount of freshwater pomfret fish consumption is increasing. Feed has an important role in increasing the production of aquaculture activities. The food provided must be of high quality, nutritious and meet the requirements for being cultivatedThis research is conducted in August 2019 to December 2019 at the Faculty of Fisheries and Marine Sciences, Universitas Padjadjaran. This study aims to determine the most effective dose of potassium diformate in feed to increase growth performance and survival of freshwater pomfret (Colossoma macropomum). This study used a completely randomized design (CRD) method with 4 treatments and 4 replications. This research was conducted for 35 days with sampling done every 7 days The treatment used is the addition of potassium diformate to commercial feed at $0 \%, 0.1 \%, 0.3 \%$, and $0.5 \%$. The parameters observed in this research are survival, specific growth rate, feed efficiency and water quality.. The results showed that $0.3 \%$ potassium diformate addition is the most effective to increase survival, specific growth rate and feed efficiency with values of $100 \%, 3.41 \%$ and $90,78 \%$ respectively.
\end{abstract}

Key words : Colossoma macropomum; Organic Acid; Feed Additive; Growth; Survival Rate.

\section{PENDAHULUAN}

Ikan bawal air tawar (Colossoma macropomum) pertama kali masuk ke Indonesia pada tahun 1986, oleh sebuah perusahaan swasta yang bergerak di bidang usaha budidaya ikan konsumsi di Tangerang, Banten. Penyebarannya mendapat respon yang tinggi dari para pembudidaya ikan di industri perikanan tanah air dan membuat jumlah konsumsi ikan bawal air tawar semakin hari semakin meningkat. Rasa daging yang gurih dan ukuran badannya cukup besar membuat ikan bawal air tawar banyak diminati oleh para pembudidaya. Salah satu kota yang memproduksi benih ikan bawal air tawar di Indonesia secara meningkat yaitu Kabupaten Bogor, pada tahun 2016 tercatat produski benih ikan bawal air tawar di Kabupaten Bogor berjumlah 77.873 ton sedangkan pada tahun 2017 tercatat produksi benih ikan bawal air tawar mencapai 97.952 ton (Dinas Perikanan dan Kelautan Kabupaten Bogor, 2017).

Usaha budidaya ikan bawal air tawar $(C$. macropomum) di Indonesia telah berkembang pesat setelah berhasil dilakukan penelitian pemijahan. Sebanyak 500 juta ekor benih ikan bawal setiap musimnya dijual ke berbagai provinsi di Indonesia terutama di Jawa Barat sebagai wilayah pengembangan ikan bawal air tawar (Arie, 2009). Untuk meningkatkan produksi budidaya dapat dicapai dengan mempercepat pertumbuhan terutama dengan pemberian pakan. Jumlah pakan yang cukup, tepat waktu dan kandungan nutrient yang sesuai dengan kebutuhan ikan harus diperhatikan untuk meningkatkan efisiensi dalam berbudidaya (Kardana et al., 2012). Tercatat harga ikan bawal air tawar pada Mei 2020 menurut situs jual beli (farmbos) memiliki nilai jual Rp 25.000/kg.

Pembudidaya ikan bawal air tawar (C.macropomum) memiliki permasalahan yang 
sering dihadapi yaitu tingginya harga pakan ikan. Pakan merupakan biaya variabel terbesar hampir 60 $\%$ dari biaya produksi. Terlebih lagi pada budidaya ikan bawal air tawar (C. macropomum) yang memiliki keuntungan yang tipis (Mamora, 2009). Pakan komersil yang biasa digunakan lalu ditambahkan dengan feed additive akan membuat pertumbuhan ikan lebih tinggi dan membuat usaha budidaya ikan bawal air tawar menjadi lebih untung. Pertumbuhan merupakan pertambahan ukuran, berupa panjang atau berat dalam waktu tertentu. Pertambahan bobot atau protein dalam tubuh dalam jangka waktu tertentu merupakan proses pertumbuhan yang terjadi dalam tubuh organisme (Effendie, 1997). Pendugaan pertumbuhan ikan dapat dilakukan dengan menganalisis data frekuensi panjang atau bobot. Makanan yang masuk ke dalam tubuh ikan tidak semuanya digunakan untuk pertumbuhan, sebagian besar energi dari makanan digunakan untuk aktivitas dan reproduksi. Protein, karbohidrat, lipid, mineral dan vitamin ditambah air serta oksigen merupakan faktor penting bagi pertumbuhan. Pertumbuhan jaringan atau organ, selain dipengaruhi oleh kualitas makanan, juga dipengaruhi oleh hormon pertumbuhan.

Asam organik adalah salah satu bahan alternatif campuran pakan yang mempelopori kegiatan akuakultur yang ramah lingkungan dan berkelanjutan. Saat ini molekul asam organik yang paling banyak diuji dalam budidaya perikanan adalah kalium diformat (KDF) tercatat KDF telah diuji pada berbagai jenis ikan dan udang, seperti ikan nila, patin, lele, mas, bandeng barramundi dan udang vaname (Addcon, 2017). Menurut Lückstädt (2017), KDF adalah bahan tambahan pakan berupa molekul asam format garam ganda yang dapat menurunkan $\mathrm{pH}$ dan menghambat bakteri patogen dalam saluran pencernaan. Keuntungan KDF untuk ikan dan udang yaitu membuat kondisi yang tidak menguntungkan bagi bakteri patogen, mendukung pencernaan protein dan mineral serta meningkatkan kinerja pertumbuhan, selanjutnya keuntungan bagi pakan sendiri yaitu melindungi bahan baku dan pakan olahan dari degradasi bakteri (Arreza, 2017).

Penelitian pemberian KDF pada ikan bawal air tawar belum pernah dilakukan. Oleh karena itu, riset ini bertujuan untuk mengetahui dosis KDF yang paling efektif untuk pertumbuhan dan kelangsungan hidup ikan bawal air tawar.

\section{METODE}

Penelitian ini dilaksanan di Laboratorium Akuakultur Gedung 4 dan Laboratorium Mikrobiologi dan Bioteknologi Fakultas Perikanan dan Ilmu Kelautan, Universitas Padjadjaran pada bulan Agustus 2019 hingga bulan Desember 2019. Riset ini menggunakan metode Rancangan Acak
Lengkap (RAL) dengan 4 perlakuan dan 4 ulangan. Perlakuan yang digunakan adalah penambahan kalium diformat pada pakan komersil dengan dosis $0 \%, 0,1 \%, 0,3 \%$ dan $0,5 \%$ per 100 gram pakan. Berapa jumlah ikan yang digunakan pada setiap ulangan? Berapa ukuran awal ikan (bobot dan panjang dalam rata-rata \pm standar deviasi).

Semua alat dan bahan yang digunakan dalam penelitian dipersiapkan. Akuarium $(39,8 \mathrm{~cm}$ x 25,4 $\mathrm{cm} \times 28 \mathrm{~cm})$ dan fiber $(1,5 \mathrm{~m} \times 1,5 \mathrm{~m} \times 1,5 \mathrm{~m})$ dibersihkan menggunakan klorin 30 ppm selama 24 jam, diberi aerasi kuat, dibilas, lalu diisi air kembali. Setelah akuarium diisi air, lalu disetting dengan memasang aerasi dan heater di masing-masing akuarium.

Pakan komersil yang digunakan adalah PF500 yang diprosuksi oleh PT Matahari Sakti dari Negara Indoensia dengan ukuran pakan sebesar 0,5$0,7 \mathrm{~mm}$. Kandungan pakan PF-500 yaitu protein $40 \%$, lemak 6\%, mostur 11 dan fiber 3\%. Pakan komersil ditimbang sebesar 100 gram untuk setiap perlakuan. KDF berbentuk serbuk ditimbang sesuai kadar setiap perlakuan, yaitu sebanyak $0,1 \% \quad 0,3 \%$ dan $0,5 \%$ dari 100 gram pakan komersil. Kalium diformat dicampurkan dengan cara diberi air sebanyak $10 \%$ lalu disemprot ke dalam pakan dan dikeringkan dengan cara diangin-anginkan. Air digunakan sebagai pelarut KDF. Campuran pakan dikeringkan lalu dijemur selama 1 jam. Campuran pakan ditimbang sebesar 3\% dari biomassa ikan setiap akuarium. Pembuatan pakan dilakukan setiap tujuh hari sekali setelah melakukan sampling pada setiap akuarium, pakan yang sudah ditimbang dimasukan ke dalam zipper lock lalu disimpan pada tempat yang kering untung menghindari kelembapan dari pakan tersebut.

Frekuensi pemberian pakan yang telah diberi KDF sebanyak 3 kali sehari yaitu pada pukul 08.00, 12.00 dan 16.00 WIB selama 35 hari, ikan bawal setiap harinya diberikan pakan dengan jumlah 3\% dari jumlah total bobot ikan pada tiap akuarium. P pengamatan parameter kelangsungan hidup, laju pertumbuhan harian dan kualitas air dilakukan tujuh hari sekali. Penyifonan akuarium dilakukan setiap hari sebelum pemberian pakan awal dan pergantian air dilakukan sebanyak enam kali selama periode pengamatan pada tujuh hari sekali

\section{Parameter Pengamatan}

Parameter pengamatan yang dilakukan pada riset ini yaitu kelangsungan hidup, laju pertumbuhan dan kualitas air.

\section{Kelangsungan Hidup (Survival Rate/SR)}

Rumus yang digunakan untuk mengetahui persentase kelangsungan hidup ikan uji menurut Effendie (2004) adalah : 


$$
\mathrm{SR}=\frac{\mathrm{Nt}}{\mathrm{No}} \times 100 \%
$$

Keterangan :

$\begin{array}{ll}\mathrm{SR} & =\text { Kelangsungan Hidup }(\%) \\ \mathrm{Nt} & =\text { Jumlah ikan akhir pemeliharaan } \\ \mathrm{No} & =\text { Jumlah ikan awal pemeliharaan }\end{array}$

\section{Pertumbuhan Harian}

Laju Pertumbuhan Harian (LPH) dengan menggunakan rumus Effendie (1997), yaitu :

$$
\mathrm{LPH}=\frac{\ln \mathrm{Wt}-\ln \mathrm{Wo}}{\mathrm{t}} \times 100 \%
$$

Keterangan :

$$
\begin{array}{ll}
\mathrm{LPH} & =\text { Laju Pertumbuhan Harian } \\
w t & =\text { bobot rata-rata pada akhir perlakuan } \\
& \quad \text { (hari ke- } \mathrm{t}) \\
\text { wo } & =\text { bobot rata-rata awal perlakuan } \\
& \quad \text { (hari ke-0) } \\
\mathrm{t} & =\text { Lama Pengamatan (hari) }
\end{array}
$$

\section{Efisiensi Pemberian Pakan}

Efisiensi pemberian pakan ikan gurame dihitung berdasarkan rumus efisiensi pakan pakan yang dikembangkan Djajasewaka (1985), yaitu

$$
\mathrm{EPP}=\frac{(\mathrm{Wt}+\mathrm{D})-\mathrm{Wo}}{\mathrm{F}} \times 100 \%
$$

Keterangan :

$$
\begin{aligned}
\mathrm{EPP}= & \text { Efisiensi Pemberian Pakan } \\
\mathrm{F} & =\text { Jumlah pakan yang diberikan selama } \\
& \text { penelitian }(\mathrm{g}) \\
\mathrm{Wt} & =\text { Biomassa pada akhir }(\mathrm{g}) \\
\mathrm{Wo} & =\text { Biomassa pada awal penelitian }(\mathrm{g}) \\
\mathrm{D} & = \\
& \text { Biomassa ikan uji yang mati selama } \\
& \text { penelitian }(\mathrm{g})
\end{aligned}
$$

\section{Kualitas Air}

Pengamatan kualitas air terdiri atas $\mathrm{pH}$, oksigen terlarut (dissolved oxygen / DO) dan suhu. Pengukuran kualitas air pada penelitian ini dilakukan setiap tujuh hari selama periode pengamatan dan waktu pengambilan sampel dilakukan pada pukul 10 pagi.

\section{Analisis Data}

Data kelangsungan hidup dan laju pertumbuhan bobot dianalisis dengan menggunakan uji analitik F 5\%. Apabila terdapat perbedaan yang nyata, maka pengujian dilanjutkan dengan uji jarak berganda Duncan (Steel \& Torrie, 1993). Sedangkan analisis kualitas air dilakukan secara deskriptif.

\section{HASIL DAN PEMBAHASAN}

\section{Kelangsungan Hidup}

Kelangsungan hidup diamati selama pemeliharaan KDF selama 35 hari dan pasca uji tantang A. hydrophila. Kelangsungan hidup selama pemeliharaan dapat dilihat pada Gambar 1.
Berdasarkan Gambar 1, presentase tingkat kelangsungan hidup ikan bawal air tawar bervariasi dengan perlakuan A yaitu 93\%, perlakuan B 95\%, perlakuan C $100 \%$ dan perlakuan D dengan nilai 93\%. Perlakuan A memiliki nilai rendah karena pada pakan ikan tidak diberikan KDF sebagai imunostimulan untuk meningkatkan kekebalan tubuh, perlakuan B memiliki nilai lebih tinggi daripada kontrol, namun dosisnya belum optimal sehingga tidak memberikan efek yang berbeda dengan kontrol. Perlakuan $\mathrm{C}$ merupakan nilai kelangsungan hidup tertinggi untuk benih ikan bawal air tawar. Perlakuan D memiliki nilai kelangsungan hidup yang menurun kembali, hal ini dikarenakan jika dosis KDF melebihi dosis optimum maka akan menggangu sistem osmoregulasi dari ikan.

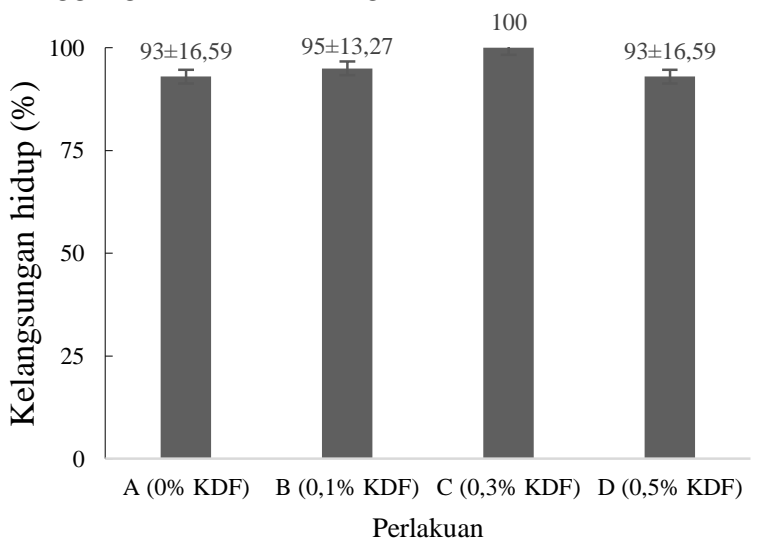

Gambar 1 Grafik kelangsungan hidup selama pemeliharaan.

Berdasarkan hasil uji $\mathrm{F}(\mathrm{p}<0,05)$ pemberian KDF pada ikan bawal air tawar dengan penambahan KDF A $(0 \%), \mathrm{B}(0,1 \%), \mathrm{C}(0,3 \%)$ dan D $(0,5 \%)$ tidak memberikan pengaruh yang nyata pada kelangsungan hidup ikan bawal air tawar. Pada perlakuan $\mathrm{C}$ tingginya nilai kelangsungan hidup dikarenakan ikan memiliki laju pertumbuhan dan efisiensi pakan yang tertinggi, sehingga pakan yang dicerna sesuai dengan kebutuhan gizinya. Kualitas air pada perlakuan $\mathrm{C}$ ini juga sesuai dengan baku mutu yang diacu dan membuat nilai kelangsungan hidup ikan bawal air tawar tinggi.

Kelangsungan hidup ikan bawal air tawar pada seluruh perlakuan dapat digolongkan tinggi. Menurut Adelina et al. (2000), spesies ikan yang mempunyai kemampuan adaptasi yang tinggi yaitu ikan bawal air tawar. Hal tersebut didukung pula oleh Arie (2000) yang mengemukakan bahwa tingkat kelangsungan hidup bawal air tawar dapat mencapai $90 \%$. Tingginya nilai kelangsungan hidup pada riset ini dikarenakan sesuainya kualitas air sesuai baku mutu ikan bawal air tawar. Pada riset ini juga dilakukan pada laboratorium yang terkontrol, yang membuat tingkat kelangsungan hidup ikan menjadi lebih tinggi dibandingkan dengan pemeliharaan pada tempat yang terbuka. Selain itu, pakan yang diberikan sudah sesuai dengan kebutuhan bawal air tawar baik ukuran, jumlah dan kandungan gizinya. 
Pakan komersil yang ditambahkan dengan KDF sebagai acidifier (zat pengasaman) akan mempercepat proses penyerapan nutrisi yang terkandung dalam pakan karena asam organik mampu menurunkan $\mathrm{pH}$ saluran pencernaan untuk membuat kondisi optimal saluran pencernaan dalam penyerapan nutrisi pakan, selain itu juga asam organik yang ditambahkan pada pakan mampu membunuh bakteri patogen dalam saluran pencernaan dan membuat bakteri komensal berkembang dengan baik.

\section{Laju Pertumbuhan}

Pertumbuhan yaitu proses yang terjadi di dalam tubuh organisme yang menyebabkan pertambahan bobot atau protein pada tubuh dalam jangka waktu tertentu. Pertambahan jaringan akibat dari pembelahan sel yang terjadi akibat kelebihan input energi dan asam amino (protein) yang berasal dari makanan merupakan pertumbuhan dalam individu (Aliyas, 2016).

Berdasarkan hasil pengamatan yang telah dilakukan, didapatkan presentase laju pertumbuhan harian ikan bawal dengan nilai yang bervariasi. Laju pertumbuhan harian tertinggi terdapat pada perlakuan $\mathrm{C}$ yaitu sebesar 3,41\% dan yang terendah pada perlakuan B sebesar 2,95\%. Laju pertumbuhan harian dapat dilihat pada Gambar 2.

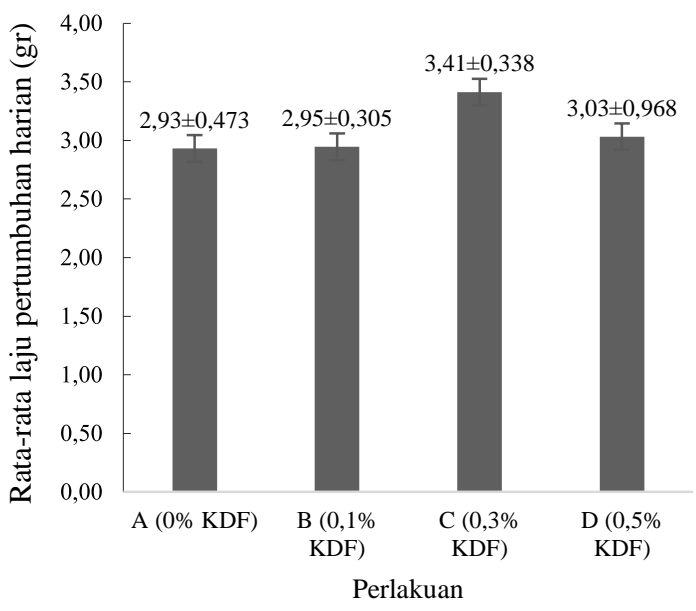

Gambar 2 Grafik laju pertumbuhan harian.

Dapat dilihat pada Gambar 2 bahwa laju pertumbuhan harian (LPH) meningkat pada dosis $0,3 \%$ lalu turun kembali pada dosis $0,5 \%$. Hasil uji $\mathrm{F}$ $(\mathrm{p}<0,05)$ menunjukkan bahwa ikan bawal dengan penambahan KDF $0,3 \%$ tidak memiliki nilai yang bebeda nyata dengan nilai yang diberi pakan dengan penambahan $0 \%, 0,1 \%$ dan $0,5 \%$. Hal tersebut mengindikasikan bahwa penambahan KDF hingga $0,5 \%$ pada pakan tidak adanya dampak negatif pada pertumbuhan ikan bawal. Tingginya nilai laju pertumbuhan pada perlakuan $\mathrm{C}$ juga dikarenakan pada efisiensi pakan perlakuan $\mathrm{C}$ merupakan nilai yang paling baik, tingginya efisiensi pakan juga berarti semakin baik kualitas pakan dan efisien pakan tersebut diubah menjadi daging dan paling tinggi untuk laju pertumbuhan.

Perlakuan C memiliki nilai pertumbuhan yang lebih baik daripada perlakuan lainnya. Penggunaan $\mathrm{KDF}$ sebagai asam organik dapat meningkatkan pertumbuhan ikan dengan cara menurunkan $\mathrm{pH}$ lambung yang lebih cepat merangsang sekresi pepsin dan pepsinogen yang selanjutnya dapat meningkatkan pencernaan protein makanan (Granli et al., 2002). Aktivitas enzim pepsin dapat optimum pada $\mathrm{pH} 2$ atau kondisi asam, dengan demikian penggunaan KDF dapat mengoptimalkan aktivitas pepsin dalam pemecahan protein menjadi peptida dengan cara menurukan $\mathrm{pH}$ usus (Yustiati et al., 2019b). Hal tersebut sesuai dengan pernyataan (Sheng \& He, 2006) asam organik yang diaplikasikan pada ikan mampu menurunkan $\mathrm{pH}$ fungsi pencernaan dalam perut. Penurunan $\mathrm{pH}$ memberi kontribusi dalam peningkatan pertumbuhan dan pemanfaatan mineral. Selain itu, peningkatan pertumbuhan terjadi karena adanya pengurangan bakteri terutama bakteri gram negatif pada saluran pencernaan. Hal ini disebabkan oleh difusi asam organik ke dalam sel bakteri yang mengakibatkan penurunan $\mathrm{pH}$ resultan sitoplasma dan terjadi kematian sel (Booth \& Stratford, 2003). Menurut Lückstädt et al. (2017), beberapa riset tentang $\mathrm{KDF}$ telah menunjukkan pengurangan jumlah bakteri pada lambung dan usus, namun Lactobacillus (bakteri asam laktat/BAL) yang bersifat menguntungkan bagi inang tidak terpengaruh bahkan meningkat jumlahnya. Salah satu kelebihan dari BAL adalah dapat memproduksi enzim proteolitik (Efendi et al., 2017), karena ikan membutuhkan protein sebagai sumber energi utama, maka penyerapan nutrisi dalam saluran pencernaan menjadi optimal dan meningkatkan pertumbuhan ikan.

Kadar KDF yang lebih tinggi pada pakan ikan tidak akan membuat laju pertumbuhan lebih meningkat, hal tersebut dikarenakan KDF adalah molekul asam format garam ganda yang dapat mengubah pencernaan dalam tubuh ikan menjadi lebih asam. Kondisi lambung tidak terlalu asam akan memudahkan penyerapan zat makanan oleh usus halu (Darwis et al., 1991). Kadar pemberian KDF $0,3 \%$ pada ikan bawal merupakan pemberian kadar KDF terbaik, karena pencernaan ikan bawal tersebut tidak terlalu asam namun pada pemberian kadar KDF $0,5 \%$ membuat pencernaan ikan bawal menjadi lebih asam dan membuat laju pertumbuhan ikan bawal terganggu. Dosis KDF yang terlalu berlebih masuk ke tubuh ikan menyebabkan energi yang dimiliki oleh ikan akan digunakan untuk menyeimbangkan metabolisme dalam tubuh atau sistem osmoregulasi, hal ini menyebabkan energi untuk laju pertumbuhan akan berkurang (Yustiati et al., 2019a).

Dosis optimal pada riset ini $(0,3 \% \mathrm{KDF})$ sesuai dengan hasil Zhou et al. (2009) dengan penambahan KDF terhadap kinerja pertumbuhan ikan nila biru (Oreochromis aureus) dengan penambahan lima perlakuan yang berbeda yaitu $0 \%$, 
$0,3 \%, 0,6 \% 0,9 \%$ dan $1,2 \%$. Dosis penambahan KDF yang paling optimal yaitu $0,3 \%$. Namun, ikan nila biru memiliki nilai LPH 2,44\% sedangkan ikan bawal memiliki nilai yang lebih tinggi yaitu $3,41 \%$. Hal tersebut mengindikasikan bahwa ikan bawal air tawar cocok untuk dibudidayakan karena pertumbuhannya yang cepat.

Rentang nilai LPH pada riset ini sesuai dengan Taufiq (2016) yang meneliti tentang ikan bawal air tawar yang diberi pakan alami yang berbeda, yang menyatakan bahwa laju pertumbuhan benih ikan bawal air tawar tertinggi terdapat pada perlakuan cacing sutera $(3,39 \%)$, jentik nyamuk $(3,25 \%)$, kutu air ( $2,88 \%)$, udang rebon $(2,83 \%)$ dan keong mas $(2,65 \%)$.

\section{Efisiensi Pemberian Pakan}

Efisiensi pemberian pakan merupakan gambaran mengenai pemberian pakan yang diberikan sehingga dapat meningkatkan pertumbuhan ikan (Nugroho, 2010). Kualitas pakan yang baik yang mempunyai efisiensi pakan tinggi sehingga pakan yang masuk dapat diubah menjadi daging dan biaya produksi menjadi lebih murah (Effendie, 2004).

Berdasarkan hasil pengamatan yang telah dilakukan didapatkan efisiensi pemberian pakan pada benih ikan bawal yaitu perlakuan $\mathrm{C}$ paling tinggi dengan nilai $90,78 \%$ selanjutnya perlakuan $\mathrm{D}$ sebesar $86,99 \%$, perlakuan A $74,19 \%$ dan perlakuan B dengan nilai paling kecil yaitu $74,08 \%$.

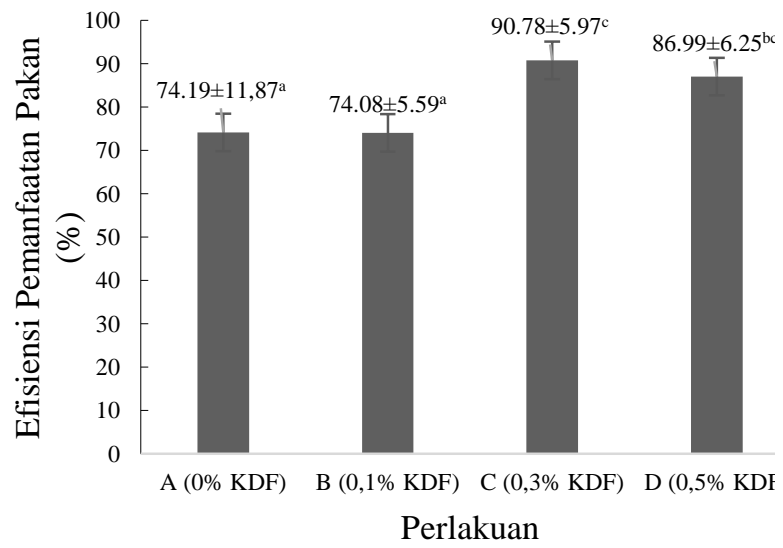

Gambar 3 Grafik efisiensi pemberian pakan.

Dapat dilihat pada Gambar 3, berdasarkan hasil uji $\mathrm{F}(\mathrm{p}<0,05)$ menunjukkan bahwa ikan bawal air tawar dengan penambahan KDF 0,3\% memiliki nilai yang berbeda nyata dengan nilai yang diberi pakan dengan penambahan $0 \%, 0,1 \%$ dan $0,5 \%$. Dugaan peneliti meningkatnya efisiensi pakan pada perlakuan pemberian KDF disebabkan karena kalium diformat membuat keadaan saluran pencernaan ikan menjadi asam. Hal ini dapat membantu meningkatkan aktivitas enzimatik yang berasimilasi kemudian dapat meningkatkan asupan pakan dan efisiensi pakan. Nugraha et al. (2020) memaparkan bahwa kalium diformat mampu membunuh sel bakteri patogen dalam saluran pencernaan dan meningkatkan jumlah bakteri komensal, sehingga nutrisi yang terdapat dalam pakan mudah terserap serta pakan yang diberikan kepada ikan tersebut dapat termanfaatkan secara efisien dan meningkatkan nilai efisiensi pemberian pakan. Namun, semakin tinggi dosis KDF yang diberikan tidak selalu akan meningkatkan efisiensi pakan ikan bawal air tawar, dikarenakan KDF berbentuk garam asam organik dan apabila penggunannya terlalu banyak akan menyebabkan gangguan osmoregulasi. Menurut Argenzio \& Eisemann (2000), penggunaan asam organik dalam dosis yang berlebihan dapat merusak mukosa perut dan duodenum. Tingginya nilai efisiensi pakan pada penelitian ini juga disebabkan karena laju pertumbuhan yang meningkat, penyerapan nutrisi dalam saluran pencernaan menjadi optimal untuk pertumbuhan akan membuat pakan yang masuk ke dalam tubuh ikan akan diolah menjadi daging.

Penambahan kalium diformat sebesar $0,3 \%$ pada perlakuan $\mathrm{C}$ menunjukan nilai efisiensi pemberian pakan tertinggi yaitu sebesar 90,78\%. Hasil ini sesuai dengan Eid et al. (2014) dan Yustiati et al. (2019a) yang menyatakan bahwa penambahan $0,3 \%$ kalium diformat menghasilkan nilai efisiensi pakan terbaik pada ikan nila (Oreochromis niloticus).

\section{Kualitas Air}

Kualitas air merupakan faktor penting untuk menentukan keberhasilan dari kegiatan budidaya ikan. Parameter kualitas air yang diamati dalam riset ini meliputi oksigen terlarut (DO), $\mathrm{pH}$ dan suhu. Pengukuran kualitas air dilakukan sebanyak delapan kali selama riset dalam kurun waktu seminggu sekali. Berikut hasil pengamatan yang dilakukan selama riset dapat dilihat pada Tabel 1 .

Tabel 1. Nilai kisaran kualitas air.

\begin{tabular}{llcc}
\hline Parameter & Satuan & $\begin{array}{c}\text { Nilai } \\
\text { Kisaran }\end{array}$ & $\begin{array}{c}\text { *Baku } \\
\text { Mutu }\end{array}$ \\
\hline Suhu & ${ }^{\circ} \mathrm{C}$ & $27-30$ & $26-30$ \\
pH & $\mathrm{mg} / \mathrm{L}$ & $5,9-7,8$ & $6-9$ \\
DO & - & $4,7-7,8$ & $5-8$ \\
\hline
\end{tabular}

(Sumber : Yanto et al., 2015)

Dapat dilihat pada Tabel 1, berdasarkan hasil pengamatan suhu air dalam riset masih dalam kisaran normal, nilai suhu $27-30^{\circ} \mathrm{C}$ masih dalam baktu mutu kualitas air.Yanto et al. (2015) untuk ikan bawal air tawar yaitu $25-30{ }^{\circ} \mathrm{C}$. Menurut Madinawati \& Serdiati (2011), untuk meningkatkan aktivitas makan dalam budidaya ikan maka diperlukan suhu yang sesuai agar ikan dapat tumbuh maksimal. Laju metabolisme yang meningkat disebabkan oleh kenaikan suhu, sehingga kebutuhan pakan bertambah dan lebih aktif dalam pengambilan pakan.

Kandungan Dissolved Oxygen (DO) pada riset ini masih berada pada kisaran normal yaitu dengan nilai DO masih dalam batasan normal yang dapat mendukung kehidupan ikan bawal air tawar. Hal ini didukung oleh pernyataan Kordi (2010), kisaran nilai 
oksigen terlarut untuk budidaya ikan berkisar antara 3-6 mg/L. Oksigen terlarut merupakan salah satu faktor paling penting dalam system perairan dan mutlak untuk respirasi (Boyd,1990).

Hasil pengukuran $\mathrm{pH}$ pada media pemeliharaan yaitu menunjukkan bahwa $\mathrm{pH}$ air selama riset adalah $\mathrm{pH}$ terbaikuntuk mendukung kehidupan benih ikan bawal air tawar. $\mathrm{pH}$ merupakan faktor pembatas serta menentukan jumlah konsumsi pakan dan kecepatan reaksi laju metabolisme (Brett, 1979). Rendahnya nilai $\mathrm{pH}$ air dapat menyebabkan terjadinya penggumpalan lendir pada insang ikan sehingga makanan yang dikonsumsi ltidak digunakan untuk pertumbuhan, melainkan untuk mempertahankan kondisi tubuh ikan itu sendiri (Zonneveld et al., 1991).

\section{SIMPULAN}

Berdasarkan hasil riset yang telah dilakukan maka dapat disimpulkan bahwa penambahan KDF $0,3 \%$ merupakan nilai dosis yang paling efektif untuk meningkatkan laju pertumbuhan harian sebesar $3,41 \%$, kelangsungan hidup dengan nilai $100 \%$ dan efisien pemberian pakan sebesar $90,78 \%$ pada ikan bawal air tawar.

\section{DAFTAR PUSTAKA}

Addcon. (2020). The Sustainable Non-Antibiotic Growth Promoter for Aquaculture. Internet. Diacu pada 15 Mei 2020 dari : https://addcon.com/index.php/en/feed/aquacu lture/aquaform.

Adelina S, Mokoginta I, Affandi R \& Jusadi D. (2000). Pengaruh Kadar Protein dan Rasio Energi Protein Pakan Berbeda terhadap Kinerja Pertumbuhan Benih Ikan Bawal Air Tawar (Colossoma macropomum). Jurnal Pertanian Indonesia, 9, (2), 31-36.

Argenzio RA \& Eisemann JH. (2000). Effects of Feed Physical Form and Buffering Solites on Water Disappearance and Proximal Stomach pH in Swine. Journal Animal Science, 1, (78), 2344- 2352.

Aliyas A. (2016). Pertumbuhan dan Kelangsungan Hidup Ikan Nila (Oreochromis sp.) yang Dipelihara pada Media Bersalinitas. Jurnal Sains dan Teknologi Tadulako, 5, (1), 19-27.

Arie U. (2000). Budidaya Bawal air Tawar untuk Konsumsi dan Ikan Hias. Jakarta: Penebar Swadaya.

Arie U. (2009). Panen Bawal 40 Hari. Jakarta: Penebar Swadaya.

Arreza J. (2017). Effect Of Dietary Potassium Diformate (KDF) On Growth Perfomance Of Juvenile Asian Seabass (Lates calcarifer) Reared Under Freshwater Conditions. Germany: Addcon.

Brett JR. (1979). Enviromental Factors and Growth. New York : Academic Press.
Booth IR \& Stratford M. (2003). Acidulants and Low $p H$. New York (US): Kluwer Academic Plenum Publishers (pp25-47).

Boyd CE. (1990). Water Quality in Ponds for Aquaqulture. Birmingham: Birmingham Publishing Co.

Darwis SN, Modjo ABD \& Hasiyah S. (1991). Tanaman Obat Familia Zingiberaceae. Bogor: Badan Penelitian dan Pengembangan Pertanian Industri.

Djajasewaka H. (1985). Pakan Ikan. Jakarta: CV. Yasaguna.

[DKP] Dinas Kelautan Perikanan Kabupaten Bogor. (2017). Data Produksi Benih Ikan Konsumsi Kabupaten Bogor Tahun 2017. Bogor: DKP Kabupaten Bogor.

Efendi Y, Yusra \& Efendi VO. (2017). Optimasi Potensi Bakteri Bacillus subtilis sebagai Sumber Enzim Protease. Jurnal Akuatika Indonesia, 2, (1), 87-94.

Effendie. (1997). Biologi Perikanan. Yogyakarta: Yayasan Pustaka Nusatama.

Effendie I. (2004). Pengantar Akuakultur. Jakarta: Penebar Swadaya.

Eid EA, Mohamed K, Ali BA \& Sayed M. (2014). Effects of Different Levels of Potassium Diformate on Growth Performance and Feed Utuilizaion of Monosex Nile Tilapia (Oreochromis niloticus) Fingerlings. Journal of Animal, Poultry and Fish Production Suez Canal University, 2, (15), 15-20.

Granli T, Overland M, Kjeldsen K \& Mroz Z. (2002). Antimicrobial properties of dietary potasium diformate in pigs. 3rd Joint Symposium RRIINRA: Beyond antimicrobials - future of gut microbiology. Aberden.

Kardana D, Haetami K \& Subhan U. (2012). Efektivitas Penambahan Tepung Maggot dalam Pakan Komersil terhadap Pertumbuhan Benih Ikan Bawal Air Tawar (Colossoma macropomum). Jurnal Perikanan dan Kelautan, 3, (4), 177-184.

Kordi K. (2010). Budidaya Ikan Lele di Kolam Terpal. Yogyakarta: Andi.

Lückstädt C. (2017). Testing Dietary Potassium Diformate in Pacific White Shrimp. Global Aquaculture Alliance. Journal of International Aquafeed, 3, (9), 6-21.

Madinawati A \& Serdiati N. (2011). Pemberian Pakan yang Berbeda Terhadap Pertumbuhan dan Kelangsungan Hidup Benih Ikan Lele (Clarias gariepinus). Jurnal Media Litbang Sulteng, 4, (2), 83-87.

Mamora M. (2009). Efisiensi Pakan Serta Kinerja Pertumbuhan Ikan Bawal (Colossoma macropomum) dengan Pemberian Pakan Berbasis Meat Bone Meal dan Pakan Komersil. Skripsi. Departemen Budidaya Perairan Fakultas Perikanan dan Ilmu Kelautan, Institut Pertanian Bogor. 
Nugraha AA, Yustiati A, Bangkit I \& Andriani Y. (2020). Growth Performance and Survival Rate of Giant Gourami Fingerlings (Osphronemus goramy Lacepede, 1801) with Potassium Diformate Addition. World Scientific News, 1 (143), 103-114.

Nugroho SJ. (2010). Pengembangan Pemakaian Limbah (Sludge) Biogas dari Kotoran Sapi sebagai Sumber Bahan Baku Pakan Nila (Oreochromis niloticus). Skripsi. Departemen Budidaya Perairan Fakultas Perikanan dan Ilmu Kelautan, Institut Pertanian Bogor.

Sheng X F \& He L Y. (2006). Solubilization of Potassium Bearing Minerals by a Wild Type Strain of Bacillus Edaphicus and its Mutants and Increased Potassium Uptake by Wheat. Canadian Journal Microbiology, 52, (1), 6672.

Steel RGD \& Torrie JH. (1993). Prinsip dan Prosedur Statistika. Terjemahan Bambang Sumantri. Jakarta: Gramedia.

Taufiq T. (2016). Pertumbuhan Benih Ikan Bawal Air Tawar (Colossoma macropomum) pada Pemberian Pakan Alami yang Berbeda. Jurnal Ilmiah Mahasiswa Kelautan dan Perikanan Unsyiah, 1, (3), 355-365.
Yanto H, Hasan H \& Sunarto. (2015). Studi Hematologi untuk Diagnosa Penyakit Ikan Secara Dini di Sentra Produksi Budidaya Ikan Air Tawar Sungai Kapuas Kota Pontianak. Jurnal Akuatika, 6, (1), 11-20.

Yustiati A, Aminah S, Walim L, Andriani Y \& Suryadi IBB. (2019a). Effect of Using Potassium Diformate as Feed Additive to Growth Rate and Feed Efficiency of Nirwana Tilapia (Oreochromis niloticus). Global Scientific Journals, 7, (8), 739-750.

Yustiati A, Nadiyah NA, Suryadi IBB \& Rosidah. (2019b). Immune Performances of Sangkuriang Catfish (Clarias Gariepinus) with Addition of Potassium Diformate on Feed. World News Of Natural Sciences, 25, (1), 113-129.

Zhou Z, Liu Y, He S, Shi P, Gao X, Yao B \& Ring Ø E. (2009). Effect of Dietary Pottasium Diformate (KDF) on Growth Performance, Feed Conversation and Intestinal Bacterial Community of Hybrid Tilapia (Oreochromis

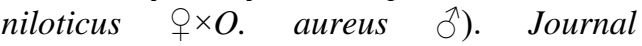
Aquaculture, 1 (291), 89-94.

Zonneveld N, Huisman EA \& Boon JH. (1991). Prinsip-Prinsip Budidaya Ikan. Jakarta: Gramedia Pustaka Utama. 